Hydrol. Earth Syst. Sci., 11, 1551-1561, 2007

www.hydrol-earth-syst-sci.net/11/1551/2007/

(C) Author(s) 2007. This work is licensed

under a Creative Commons License.

\title{
Uncertainty in geological and hydrogeological data
}

\author{
B. Nilsson, A. L. Højberg, J. C. Refsgaard, and L. Troldborg \\ Geological Survey of Denmark and Greenland, Copenhagen, Denmark \\ Received: 26 April 2006 - Published in Hydrol. Earth Syst. Sci. Discuss.: 31 August 2006 \\ Revised: 29 November 2006 - Accepted: 7 September 2007 - Published: 11 September 2007
}

\begin{abstract}
Uncertainty in conceptual model structure and in environmental data is of essential interest when dealing with uncertainty in water resources management. To make quantification of uncertainty possible is it necessary to identify and characterise the uncertainty in geological and hydrogeological data. This paper discusses a range of available techniques to describe the uncertainty related to geological model structure and scale of support. Literature examples on uncertainty in hydrogeological variables such as saturated hydraulic conductivity, specific yield, specific storage, effective porosity and dispersivity are given. Field data usually have a spatial and temporal scale of support that is different from the one on which numerical models for water resources management operate. Uncertainty in hydrogeological data variables is characterised and assessed within the methodological framework of the HarmoniRiB classification.
\end{abstract}

\section{Introduction}

Uncertainty of geological and hydrogeological features is of great interest when dealing with uncertainty in relation to the EU Water Framework Directive (WFD) (European Commission, 2000). One of the key sources of uncertainty of importance for evaluating the effect and cost of a measure in relation to preparing a WFD-compliant river basin management plan is to assess uncertainty on model structure, input data and parameter variables in relation to hydrological models. Uncertainty in hydrogeological variables is typically done by the use of numerical models.

Neuman and Wierenga (2003) summarise where uncertainties in model results originate from in addition to parameter uncertainty. Uncertainties arise firstly from incomplete definitions of the final conceptual framework that determines

Correspondence to: $\mathrm{B}$. Nilsson

(bn@geus.dk) model structure; secondly from spatial and temporal variations in hydrological variables that are either not fully captured by the available data or not fully resolved by the model; and finally from the scaling behaviour of the hydrogeological variables. Whereas much has been written about the mathematical component of hydrogeological models, relatively little attention has been devoted to the conceptual component. In most mathematical models of subsurface flow and transport, the conceptual framework is assumed to be given, accurate and unique (Dagan et al., 2003).

Structural uncertainty has long been recognized to be a dominating factor (Carrera and Neuman, 1986; Harrar et al., 2003; Troldborg, 2004; Højberg and Refsgaard, 2005; Poeter and Anderson, 2005; Eaton, 2006). This is especially important in groundwater modelling, where the geological structure is dominant for the groundwater flow but where specific knowledge of the geology at the same time is very limited. Simulating flow through heterogeneous geological media requires that the numerical models capture the important aspects of the flow domain structures. Only a very sparse selection of operational methods has been developed to quantify structural uncertainties in geological models.

In the international literature significant attention has been given to estimation of parameter uncertainty for parameter values that may vary over many decades, and for that reason, may not be measured directly but are derived from model calibration (e.g. Samper et al., 1990; Poeter and Hill, 1997; Cooley, 2004). Scaling behaviour of hydrogeological variables is another challenge within the hydrological science.

The HarmoniRiB data uncertainty assessment methodology provide a new structured framework for describing data uncertainty. Its application to different disciplines are described in other papers in this HESS special issue (Refsgaard et al., 2006b; Rode and Suhr, 2006; van der Keur and Iversen, 2006). The present paper deals with assessing the uncertainty in geological and hydrogeological data. The overall aim is to illustrate how currently available techniques and results

Published by Copernicus Publications on behalf of the European Geosciences Union. 
can be used to describe the uncertainty related to geological and hydrogeological data at the river basin scale. Specific objectives are firstly to characterize uncertainty within the methodological framework given by Brown et al. (2005) and van Loon and Refsgaard (2005). Secondly, based on published information, to give examples on variability from literature on input data, parameter values and geological model structure interpretations. This paper will have main focus on physical data uncertainty in the saturated zone unlike van der Keur and Iversen (2006), that primarily covers the physical and chemical data in the unsaturated zone.

The present work in this paper is part of an ongoing research project, HarmoniRiB, that is supported under EU 5th Framework Programme. The overall goal of HarmoniRiB is to develop methodologies for quantifying uncertainty and its propagation from raw data to concise management information. The HarmoniRiB framework application is briefly outlined in Sect. 3.3, while Refsgaard et al. (2005) present further details about the HarmoniRiB project.

\section{Uncertainty in geological model structure}

\subsection{What is a hydrogeological conceptual model?}

Many scientists and practitioners have difficulties finding consensus on defining terminology and guiding principles on hydrogeological conceptual modelling. Neuman and Wierenga (2003) describe a hydrogeological model as a framework that serves to analyse, qualitatively and quantitatively, subsurface flow and transport at a site in a way that is useful for review and performance evaluation.

Anderson and Woessner (1992) point out that a conceptual model is a simplification of the problem, where the associated field data are organised in such a way, that the system can be analysed more readily. When numerical modelling is considered the conceptual model should define the hydrogeological structures relevant to be included in the numerical model given the modelling objectives and requirements, and help to keep the modeller tied into reality and exert a positive influence on his subjective modelling decisions. The nature of the conceptual model determines the dimensions of the model and the design of the grid.

An important part of the conceptual model for groundwater modelling is related to the geological structure and how this is represented in the numerical model. Among hydrogeologists it is very common to use the hydrofacies modelling approach to construct conceptual models for specific types of sedimentary environments. Hydrofacies or hydrogeological facies are used for homogeneous but not necessarily isotropic hydrogeological units that are formed under conditions, which lead to similar characteristic hydraulic properties (Anderson, 1989). Numerous papers address the hydrogeological conceptualisation using hydrofacies: e.g. in glacial melt water-stream sediment and till (An- derson, 1989), buried valley aquifers (Ritzi et al., 2000); and alluvial fan depositional systems (Weissmann and Fogg, 1999). Comprehensive reviews and compilations of this issue can be found in e.g. Koltermann and Gorelick (1996) and Fraser and Davis (1998).

\subsection{Where do uncertainties arise from in conceptual mod- els?}

Descriptive methods are used to create images of subsurface geological depositional architecture by combining sitespecific and regional data with conceptual depositional models and geological insight. For a given field site, descriptive methods produce one deterministic image of the aquifer architecture, acknowledging heterogeneity but not describe it in a deterministic way at scales ranging from stratigraphical features (m scale) to basin fill (river basin scale). Large scale heterogeneity may be recognised but most often smaller scale heterogeneity is not captured. Often, sedimentary strata are divided into multiple layers designated as aquifers or aquitards. The assumption is made that geological facies define the spatial arrangement of hydraulic properties dominating groundwater flow and transport behaviour (Anderson, 1989; Fogg, 1986; Klingbeil et al., 1999; Bersezio et al., 1999; Willis and White, 2000). This assumption can be checked using hydraulic property measurements to define facies.

\subsection{Strategies on assessing uncertainty in the geological} model structure

Errors in the conceptual model structure may be analysed by considering different conceptualisations or scenarios. In the scenario approach a number of alternative plausible conceptual models are formulated and applied in a model to provide model predictions. The differences between the model predictions based on the alternative conceptualisations are then taken as a measure of the model structure uncertainty.

The influence of different model conceptualisations may be evaluated by having alternative conceptual models based on different geological interpretations (Selroos et al., 2001; National Research Council, 2001). Harrar et al. (2003) and Højberg and Refsgaard (2005) present two different examples, both using three different conceptual models, based on three alternative geological interpretations for multi-aquifer system representative of eastern part of Denmark with glacial till plains (Højberg and Refsgaard, 2005) and in sandy outwash plains in the western part of Denmark (Harrar et al., 2003). Each of the models was calibrated against piezometrical head data using inverse optimisation. In both studies, the three models performed equally well in reproducing the groundwater head used for calibration. Using the models in predictive mode they resulted in very similar well field capture zones. However, when the models were used to extrapolate beyond the calibration data for predictions of solute 


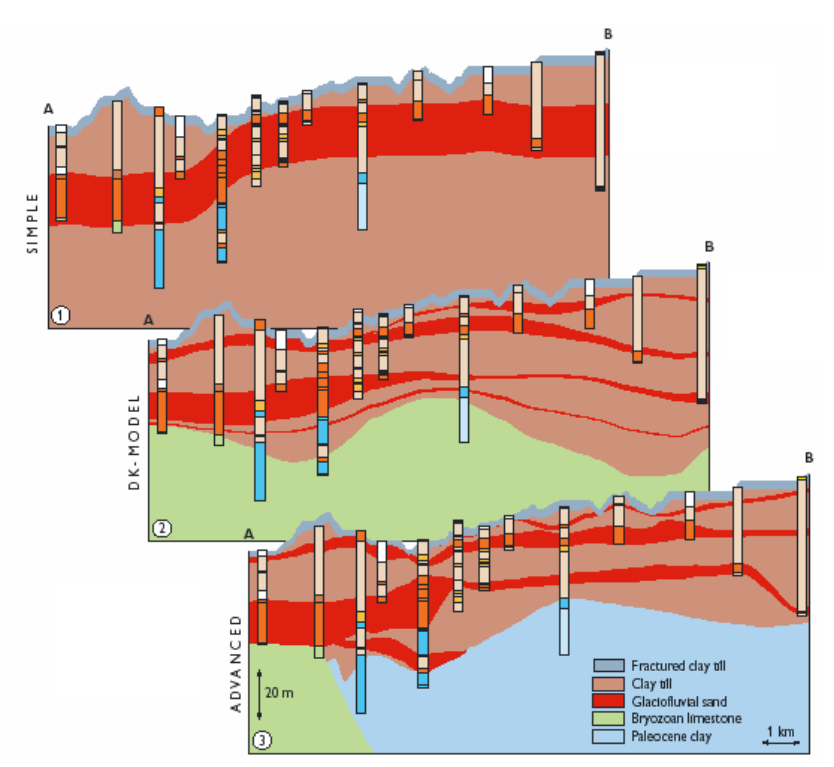

Fig. 1. Geological complexity and simulated age distribution. In a simple (upper), in an intermediary (middle), and in a complex hydrogeological conceptual model (lower). From Troldborg (2000).

transport and travel times the three models differed dramatically. When assessing the uncertainty contributed by the model parameter values using Monte Carlo simulations, the overlap of uncertainty ranges between the three models by Højberg and Refsgaard (2005) significantly decreased when moving from groundwater heads to capture zones and travel times. The larger the degree of extrapolation, the more the underlying conceptual model dominates over the parameter uncertainty and the effect of calibration. However, the parameter uncertainty can not compensate for the variability (uncertainty) in the geological model structure.

The importance of geological interpretations on groundwater flow and age (particle tracking) predictions have been studied by Troldborg $(2000,2004)$. Using a zonation approach three different conceptual models were constructed based on an extensive borehole database (Fig. 1). The three models differed in complexity. Calibrations of the models were performed using inverse calibration against hydraulic head and discharge measurements. Numerical simulation of groundwater age was carried out using a particle tracking model. Although the three models provided very similar calibration fits to groundwater heads, a model extrapolation to predictions of groundwater ages revealed very significant differences between the three models, which were explained by the differences in underlying hydrogeological interpretations.

Conditional geostatistical simulations is frequently used to address issues related to spatial distribution of conductivity (de Marsily et al., 1998; Kupfersberger and Deutsch, 1999). Most frequently, though, it is used after conceptualization

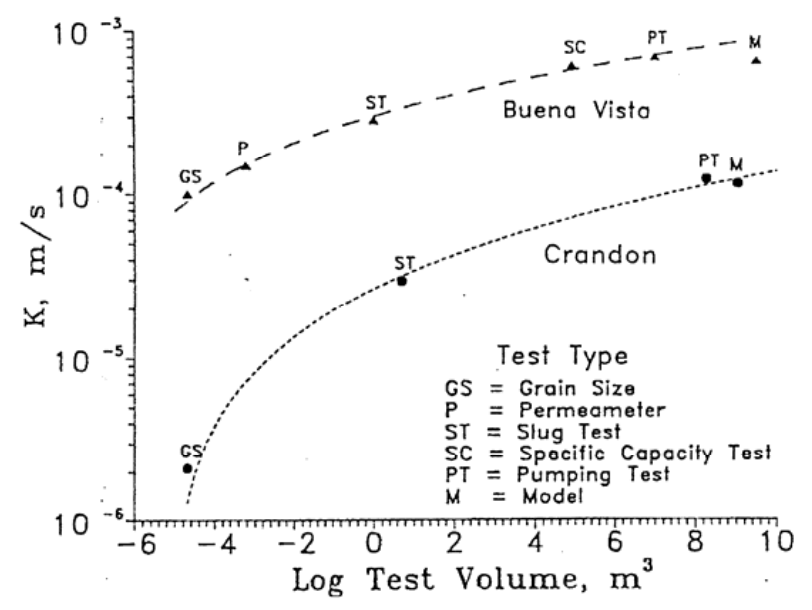

Fig. 2. Relationship between the geometric mean measured hydraulic conductivity and the support volume (sample size) for different field measurement methods in coarse-grained fluvial sediments in Wisconsin. From Bradbury and Muldoon (1990).

of aquifer structures to generate conditional realizations of conductivity within hydrological units (facies) e.g. input for Monte Carlo analysis. A good example of this is found in Zimmerman et al.(1998), where they compared seven different geostatistical approaches in combination with inverse modelling to simulate travel times and travel paths of conservative tracer through four synthetic aquifer data sets.

Geostatistical methods that can simulate hydrofacies distributions at different scale are divided into structural and process imitating methods (Koltermann and Gorelick, 1996). De Marsily et al. (1998) point out that process imitating methods cannot be conditioned to local available information. Carle and Fogg (1996 and 1997) present a transition probability geostatistical framework that can be conditioned to hard as well as soft data in simulating hydrofacies distributions. There are several examples on application which include simulation of alluvial fan systems (Fogg et al., 1998; Weissmann et al., 1999; Weissmann and Fogg, 1999), river valley aquifer systems (Ritzi et al., 1994; Ritzi et al., 2000), Quaternary aquifer complex (Troldborg et al., 2007 ${ }^{1}$ ) and sandlenses distribution within glacial till in (Sminchak et al., 1996; Petersen et al., 2004).

Neuman and Wieranga (2002) present a generic strategy that embodies a systematically and comprehensive multiple conceptual model approach, including hydrogeological conceptualisation, model development and predictive uncertainty analysis. The strategy encourages an iterative approach to modelling, whereby an initial

\footnotetext{
${ }^{1}$ Troldborg, L., Refsgaard, J. C., Jensen, K. H., Engesgaard, P., and Carle, S. F.: Application of transition probability geostatistics in hydrological modelling of a Quaternary aquifer complex, in preparation, 2007.
} 
Table 1. Classification of scales of sedimentary heterogeneity (From Koltermann and Gorelick, 1996).

\begin{tabular}{|c|c|c|c|c|c|c|}
\hline Scale name: & Basin & $\begin{array}{l}\text { Depositional environ- } \\
\text { ments }\end{array}$ & Channels & Stratigraphical features & Flow regime features & Pores \\
\hline $\begin{array}{l}\text { Approximate } \\
\text { length scale }\end{array}$ & $3 \mathrm{~km}->100 \mathrm{~km}$ & $80 \mathrm{~m}-3 \mathrm{~km}$ & $5 \mathrm{~m}-80 \mathrm{~m}$ & $0.1 \mathrm{~m}-5 \mathrm{~m}$ & $2 \mathrm{~mm}-0.1 \mathrm{~m}$ & $<2 \mathrm{~mm}$ \\
\hline Geologic features & $\begin{array}{l}\text { Basin geometry, strata } \\
\text { geometries, structural } \\
\text { features, lithofacies, } \\
\text { regional facies trends }\end{array}$ & $\begin{array}{l}\text { Multiple facies, facies } \\
\text { relations, morphologic } \\
\text { features }\end{array}$ & $\begin{array}{l}\text { Channel geometry, bed- } \\
\text { ding type and extent, } \\
\text { lithology, fossil content }\end{array}$ & $\begin{array}{l}\text { Abundance of sedimen- } \\
\text { tary structures, stratifi- } \\
\text { cation type, upward fin- } \\
\text { ing/or coarsening }\end{array}$ & $\begin{array}{l}\text { Primary sedimentary } \\
\text { structures: ripples, } \\
\text { cross-bedding, parting } \\
\text { lineation, lamination, } \\
\text { soft sediment deforma- } \\
\text { tion }\end{array}$ & $\begin{array}{l}\text { Grain size, shape, sort- } \\
\text { ing, packing, orienta- } \\
\text { tion, composition, ce- } \\
\text { ments, interstitial clays }\end{array}$ \\
\hline $\begin{array}{l}\text { Heterogeneity } \\
\text { affected by }\end{array}$ & $\begin{array}{l}\text { Faults (sealing) folding, } \\
\text { External controls (tec- } \\
\text { tonic, sea level, cli- } \\
\text { matic history), thickness } \\
\text { trends, unconformities }\end{array}$ & $\begin{array}{l}\text { Fractures (open or tight), } \\
\text { intra-basinal controls (on } \\
\text { fluid dynamics and depo- } \\
\text { sitional mechanism) }\end{array}$ & $\begin{array}{l}\text { Frequency of shale beds, } \\
\text { sand and shale body ge- } \\
\text { ometries, sediment load } \\
\text { composition }\end{array}$ & $\begin{array}{l}\text { Bed boundaries, minor } \\
\text { channels, bars, dunes }\end{array}$ & $\begin{array}{l}\text { Uneven diagenetic pro- } \\
\text { cesses, sediment trans- } \\
\text { port mechanisms, biotur- } \\
\text { bation }\end{array}$ & $\begin{array}{l}\text { Provenance, diagene- } \\
\text { sis, sediment transport } \\
\text { mechanisms }\end{array}$ \\
\hline $\begin{array}{l}\text { Observations/ } \\
\text { measurement tech- } \\
\text { niques }\end{array}$ & $\begin{array}{l}\text { Maps, seismic profiles, } \\
\text { cross-sections }\end{array}$ & $\begin{array}{l}\text { Maps, cross-sections, } \\
\text { lithologic and geo- } \\
\text { physical logs, seismic } \\
\text { profiles }\end{array}$ & $\begin{array}{l}\text { Outcrop, cross-well to- } \\
\text { mography, lithologic and } \\
\text { geophysical logs }\end{array}$ & $\begin{array}{l}\text { Outcrop, lithologic and } \\
\text { geophysical logs }\end{array}$ & $\begin{array}{l}\text { Core plug, hand sample, } \\
\text { outcrop }\end{array}$ & $\begin{array}{l}\text { Thin section, hand lens, } \\
\text { individual clast, aggre- } \\
\text { gate analysis }\end{array}$ \\
\hline $\begin{array}{l}\text { Support volume of } \\
\text { hydraulic measure- } \\
\text { ments }\end{array}$ & $\begin{array}{l}\text { Shallow crustal proper- } \\
\text { ties }\end{array}$ & $\begin{array}{l}\text { Regional (long term } \\
\text { pumping or tracer tests) }\end{array}$ & $\begin{array}{l}\text { Local (short term pump- } \\
\text { ing or tracer tests) }\end{array}$ & $\begin{array}{l}\text { Near-well (non-pumping } \\
\text { tests-height of screened } \\
\text { interval) }\end{array}$ & $\begin{array}{l}\text { Core plug analysis (per- } \\
\text { meameter) }\end{array}$ & $\begin{array}{l}\text { Several pores (mini- } \\
\text { permeameter) }\end{array}$ \\
\hline
\end{tabular}

Table 2. The sources of uncertainty on groundwater head values and the assessed error values in this respect. Modified from Sonnenborg (2001).

\begin{tabular}{|c|c|c|}
\hline Source of uncertainty & Type of uncertainty & Assessed error value \\
\hline Field instruments & Measurement error & Assessed to be: $0.1 \mathrm{~m}$ \\
\hline Level of well & $\begin{array}{l}\text { Errors in assessing the level of the } \\
\text { well, relative to which the obser- } \\
\text { vation is made. }\end{array}$ & $\begin{array}{l}\text { Assessed on the basis of topo- } \\
\text { graphic maps: } 1.5 \mathrm{~m}\end{array}$ \\
\hline Location of well & $\begin{array}{l}\text { Scaling errors as the well may } \\
\text { be located randomly within the } \\
1 \mathrm{~km}^{2} \text { model grid. }\end{array}$ & $\begin{array}{l}\text { Estimated as a typical hydraulic } \\
\text { gradient multiplied by half the } \\
\text { grid size: } 1.5 \mathrm{~m}\end{array}$ \\
\hline Geological heterogeneity & $\begin{array}{l}\text { Scaling error due to geologi- } \\
\text { cal heterogeneity within a model } \\
\text { grid. }\end{array}$ & $\begin{array}{l}\text { According to Gelhar (1986) to } \\
\text { be assessed as the autocorrelation } \\
\text { length scale for log K multiplied } \\
\text { to the standard deviation of log K } \\
\text { and the average hydraulic gradi- } \\
\text { ent: } 2.1 \mathrm{~m}\end{array}$ \\
\hline Non-stationarity & $\begin{array}{l}\text { Error due to non-stationarity. The } \\
\text { observed data originate from dif- } \\
\text { ferent seasons. }\end{array}$ & $\begin{array}{l}\text { The error may be assessed as } \\
\text { half the typical annual fluctua- } \\
\text { tion: } 0.5 \mathrm{~m}\end{array}$ \\
\hline Other effects & $\begin{array}{l}\text { E.g. due to vertical scaling error } \\
\text { and variations in topography. }\end{array}$ & Assessed to be: $0.5 \mathrm{~m}$ \\
\hline
\end{tabular}

conceptual-mathematical model is gradually altered and/or refined until one or more likely alternatives have been identified and analysed.

Professionals within the discipline have not yet agreed upon a procedure for ranking or weighting conceptual models. Poeter and Anderson (2005) introduce a multimodel ranking and interference, which is a simple and effective approach for the selection of a best model: one that balances under fitting with over fitting. Neuman and Wierenga (2003) propose and apply the Maximum Likelihood Bayesian Averaging (MLBA) approach for assessment of the joint pre- dictive uncertainties in the conceptual-mathematical model structure and its parameters. Finally, Refsgaard et al. (2006a) propose a strategy that combines multiple conceptual models and the pedigree approach (Funtowicz and Ravetz, 1990) for assessing the overall tenability of models in one formalised protocol. The level of subjectivity can to some degree be reduced using expert elicitation, which is a structured process to elicit subjective judgements from experts. 
Table 3. Data on variance and correlation scales of the natural logarithm of hydraulic conductivity or transmissivity (From Gelhar, 1993).

\begin{tabular}{|c|c|c|c|c|c|}
\hline \multirow[t]{2}{*}{ Medium } & \multirow{2}{*}{$\begin{array}{l}\text { Standard } \\
\text { deviation } \\
\text { (m) }\end{array}$} & \multicolumn{2}{|c|}{ Correlation length $(\mathrm{m})$} & \multicolumn{2}{|c|}{ Correlation scale $(\mathrm{m})$} \\
\hline & & horizontal & vertical & horizontal & vertical \\
\hline \multicolumn{6}{|c|}{ Transmissivity data (depth-averaged observations based on pump tests) } \\
\hline alluvial aquifer & 0.6 & 150 & & 5000 & \\
\hline alluvial aquifer & 0.8 & 820 & & 5000 & \\
\hline alluvial-basin aquifer & 1.0 & 800 & & 20000 & \\
\hline alluvial aquifer & 0.4 & 1800 & & 25000 & \\
\hline alluvial-basin aquifer & 1.22 & 4000 & & 30000 & \\
\hline limestone aquifer & 2.3 & 6300 & & 30000 & \\
\hline limestone aquifer & 2.3 & 3500 & & 40000 & \\
\hline sandstone aquifer & 1.4 & 17500 & & 50000 & \\
\hline chalk aquifer & 1.7 & 7500 & & 80000 & \\
\hline sandstone aquifer & 0.6 & $4.5 \times 10^{4}$ & & $5 \times 10^{5}$ & \\
\hline \multicolumn{6}{|c|}{ Soils (based on observed vertical infiltration rates at ground surface) } \\
\hline alluvial silty-clay loam soil & 0.6 & 0.1 & & 6 & \\
\hline weathered shale subsoil & 0.8 & $<2$ & & 14 & \\
\hline prairie soil & 0.6 & 8 & & 100 & \\
\hline Homra red Mediterranean soil & $0.4-1.1$ & $14-39$ & & 100 & \\
\hline alluvial soil & 0.9 & 15 & & 100 & \\
\hline fluvial soil & 1.0 & 7.6 & & 760 & \\
\hline gravely loamy sand soil & 0.7 & 500 & & 1600 & \\
\hline \multicolumn{6}{|c|}{ Three-dimensional aquifer data } \\
\hline fluvial sand & 0.9 & $>3$ & 0.1 & 14 & 5 \\
\hline glacial-lacustrine sand aquifer & 0.6 & 3 & 0.12 & 20 & 2 \\
\hline glacial outwash sand & 0.5 & 5 & 0.26 & 20 & 5 \\
\hline outwash sand and gravel outcrop & 0.8 & 5 & 0.4 & 30 & 30 \\
\hline eolian sandstone & 0.4 & 8 & 3 & 30 & 60 \\
\hline fluvial sand and gravel aquifer & 2.1 & 13 & 1.5 & 90 & 7 \\
\hline sand and gravel aquifer & 1.9 & 20 & 0.5 & 100 & 20 \\
\hline sandstone aquifer & $1.5-2.2$ & & $0.3-1.0$ & & 100 \\
\hline
\end{tabular}

\section{Uncertainty in hydrogeological data}

\subsection{Scaling issues}

One of the great and very general challenges within the hydrological science is to understand the impact of changing scales on various process descriptions and parameter values. The average volume of hydrogeological measurements (also named support volume) is ranging many orders of magnitude depending on the size of volume representing the individual measurements. Spatial heterogeneity as a function of scale is well documented in the literature for saturated hydraulic conductivity (Clauser, 1992, Sánchez-Vila et al., 1996; Nilsson et al., 2001). Values of the saturated hydraulic conductivity depend on the volume of substrate sampled by the applied hydraulic testing method. A literature example in coarsegrained fluvial sediments (Bradbury and Muldoon, 1990) is shown in Fig. 2. It is evident that the mean hydraulic conductivity increases as the support volume of the tests increases.
Aquifers contain many scales of hydrofacies or hydrogeological facies, which controls the hydraulic conductivity structure. The descriptive nature of many classifications makes them somewhat subjective; however, they provide a useful basis for comparison between multiple scales of geological heterogeneity (Koltermann and Gorelick, 1996) (Table 1). Scales of geological and hydraulic conductivity structure are based on (a) size of the geological features, (b) genetic origin, (c) support length (porous media measurement volumes).

An example dealing with upscaling of uncertainty on groundwater heads from a point scale to a $1 \mathrm{~km}^{2}$ grid scale is given in Henriksen et al. (2003). Groundwater head data are measured in observation wells, i.e. with a measurement support scale of a few $\mathrm{cm}^{2}$. When used to compare with simulated heads simulated by a groundwater model with a spatial resolution of $1 \mathrm{~km}^{2}$ the relevant uncertainty of the measured head should also include its uncertainty in representing average groundwater head over the $1 \mathrm{~km}^{2}$. In addition the point 


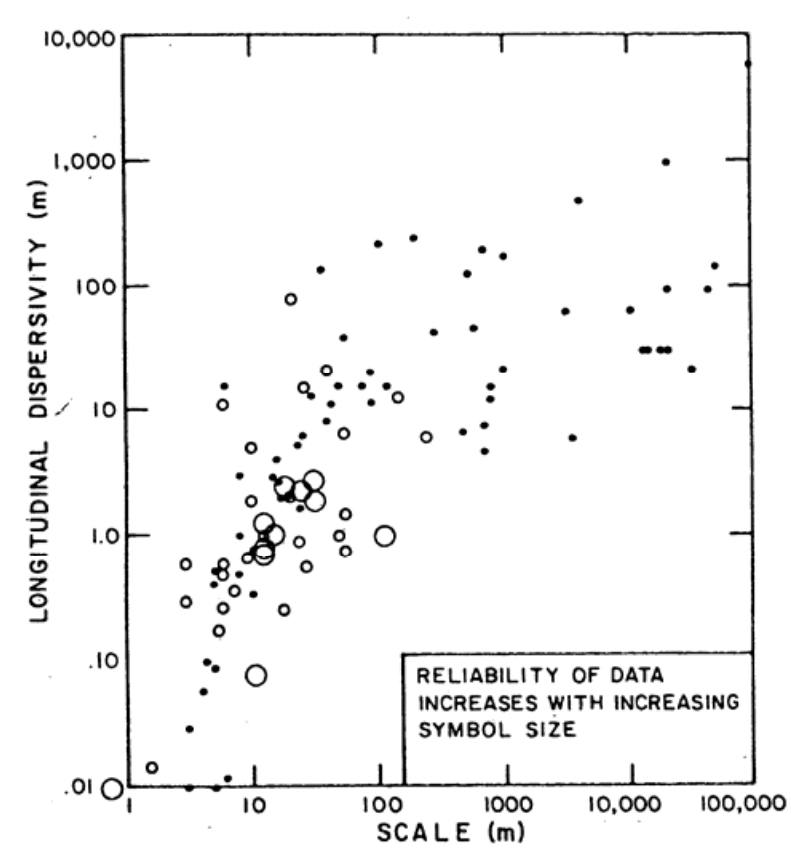

Fig. 3. Longitudinal dispersivity data plotted versus scale of experiment; the largest symbols indicate the most reliable data. (Gelhar, 1986).

scale value representing a small time scale (e.g. $10 \mathrm{~s}$ ) should be upscaled to show its representativeness of an average annual value, taking the seasonal variations into account. The sources of uncertainty and their respective contributions in this respect are shown in Table 2. Assuming mutual independence between these individual errors the aggregated uncertainty of the observed head data relative to model simulations at a $1 \mathrm{~km}^{2}$ scale can be estimated as the square root of the sum of the squared errors, summing up to $3.1 \mathrm{~m}$.

\subsection{Variability on hydraulic properties}

Data on spatial variability investigated by means of geostatistical methods have obtained significant attention in the scientific literature (Isaaks and Srivastava, 1989). For all practical purposes at the time scales relevant for this paper the variables are considered invariant. Several studies have focused on the determination of spatial correlation length scales for different hydraulic properties (e.g. Dagan, 1986; Gelhar, 1993). Variability becomes uncertain because it cannot be captured by direct field or laboratory measurements. Instead, the parameter variability is recognised by the geostatistical measure like mean, variance and correlation length.

\subsubsection{Hydraulic conductivity (K)}

Gelhar (1993) summarise the standard deviation and correlation lengths $(\lambda)$ of hydraulic conductivity from several field studies in Table 3, which covers a wide range of field scales
Table 4. Value ranges of effective porosity (n), specific yield $\left(S_{y}\right)$ and specific storage $\left(\mathrm{S}_{S}\right)$. Data sources: a) Freeze and Cherry (1979), b) Anderson (1989), and c) Smith and Weathcroft (1992).

\begin{tabular}{llll}
\hline Material & $\mathrm{n}^{\mathrm{a})}$ & $\mathrm{S}_{y}{ }^{\mathrm{b}+\mathrm{c})}$ & $\mathrm{S}_{s}^{\mathrm{b}+\mathrm{c})}$ \\
\hline Gravel & $25-40$ & $0.2-0.4$ & $10^{-4}-10^{-6}$ \\
Sand & $25-50$ & $0.1-0.3$ & $10^{-3}-10^{-5}$ \\
Clay & $40-70$ & $0.01-0.1$ & $10^{-3}-10^{-4}$ \\
Sand and gravel & $20-35$ & $0.15-0.25$ & $10^{-3}-10^{-4}$ \\
Sandstone & $5-30$ & $0.05-0.15$ & $10^{-3}-10^{-5}$ \\
Limestone & $0-20$ & $0.005-0.05$ & $10^{-3}-10^{-5}$ \\
Shale & $0-10$ & $0.005-0.05$ & $10^{-3}-10^{-5}$ \\
\hline
\end{tabular}

and seems to indicate that the length scale of field data for which correlation length and standard deviation have been assessed increases with increasing field scale.

Different measurement techniques used to determine saturated hydraulic conductivity representing 13 orders of magnitude in a coarse-grained fluvial material are shown in Fig. 2. The hydraulic conductivity of various geological materials is ranging multiple orders of magnitude with unfractured bedrocks and matrix permeability in glacial tills in the lower end and unconsolidated sediments in the middle to upper end.

\subsubsection{Storage coefficients, effective porosity and dispersiv- ity}

Correlation lengths of specific yield $\left(S_{y}\right)$, specific storage $\left(\mathrm{S}_{S}\right)$ and effective porosity $(\mathrm{n})$ are not found in the literature. The range of values related to different soil types are available (Table 4). The longitudinal dispersivity $(\alpha)$ has been compiled in Fig. 3 from many field sites with very different geological setting around the world (Gelhar, 1986). These data indicates that a longitudinal dispersivity in the range of 1 to $10 \mathrm{~m}$ would be reasonable for a site of dimensions on the order of $1 \mathrm{~km}$, whereas the range of 10 to $1000 \mathrm{~m}$ would cover the river basin length scale on the order of few $\mathrm{km}$ to more than $100 \mathrm{~km}$. The dispersivity value typically varies by 2 to 3 orders of magnitude depending on which length that are of interest.

\subsection{Classification of data uncertainty in accordance to Har- moniRiB terminology and classes}

As part of the data processing the HarmoniRiB project partners have characterised and assessed the data uncertainty using the new methodology described by Brown et al. (2005) and using the DUE (Data Uncertainty Engine) software tool (Brown and Heuvelink, 2006). This new methodology has been further elaborated in van Loon and Refsgaard (2005).

The new methodology comprises an integrated framework for assessing and recording uncertainties about environmental data. It provides sufficient flexibility for application to 
Table 5. The subdivision and coding of attribute uncertaintycategories, along the "axes" of space-time variability and measurement scale (van Loon and Refsgaard, 2005).

\begin{tabular}{llll}
\hline Space-time variability & \multicolumn{3}{c}{ Measurement scale } \\
& $\begin{array}{l}\text { Continuous } \\
\text { numerical }\end{array}$ & $\begin{array}{l}\text { Discrete } \\
\text { numerical }\end{array}$ & Categorical \\
\hline Constant in space and time & A1 & A2 & A3 \\
Varies in time, not in space & B1 & B2 & B3 \\
Varies in space, not in time & C1 & C2 & C3 \\
Varies in time and space & D1 & D2 & D3 \\
\hline
\end{tabular}

Table 6. Types of empirical uncertainty (van Loon and Refsgaard, 2005).

\begin{tabular}{ll}
\hline Code & Explanation \\
\hline M1 & Probability distribution or upper \& lower bounds \\
M2 & Qualitative indication of uncertainty \\
M3 & Some examples of different values a variable may take \\
\hline
\end{tabular}

various fields of hydrology without being overly complex. The methodology is based on a distinction between the empirical quality of data and the sources of uncertainty in data.

\subsubsection{Attribute, empirical and longevity uncertainty}

By considering space-time variability and data type 13 uncertainty categories of uncertain data are distinguished between (Table 5). In addition it is useful to distinguish the methods for describing uncertainty, which depend on the type and amount of information available (Table 6). The source of uncertainty related to relative age (denoted by the term "longevity") has been given in Table 7. Often, the identification of sources of uncertainty, such as instrument accuracy, errors due to under-sampling or differences in definitions, help in properly identifying the category or probability distribution function (pdf) of empirical uncertainty (Table 8). Tables 5-8 show the key characteristics used to characterise data uncertainty in the following hydrogeological variables.

The specific yield, effective porosity and dispersivity are all assessed to typically have a measurement space support of about $100 \mathrm{~cm}^{3}$. Hydraulic conductivity and specific storage have a measurement space support scale ranging from $10^{-5}$ to $10^{9} \mathrm{~m}^{3}$ depending on sample size of the applied method to determine the variable. The uncertainty category is for all variables classified as $\mathrm{C} 1$ (cf. Table 5), which means that they are assumed to vary continuously in space but not in time. The type of empirical uncertainty is classified as M1 (Table 6) for all five parameters implying that uncertainty can be characterised statistically by use of probability density functions. The relative age of uncertainty description is
Table 7. Codes for "longevity'; of uncertainty information (van Loon and Refsgaard, 2005).

\begin{tabular}{ll}
\hline Code & Explanation \\
\hline L0 & $\begin{array}{l}\text { Temporal variability of the uncertainty } \\
\text { information is unknown. } \\
\text { L1 }\end{array}$ \\
& $\begin{array}{l}\text { The uncertainty information is known to } \\
\text { change significantly over time (specify how } \\
\text { fast it changes if you know it). }\end{array}$ \\
L2 & $\begin{array}{l}\text { Uncertainty does not change significantly, } \\
\text { in principle no updating required. }\end{array}$ \\
\hline
\end{tabular}

classified as L2 (Table 7) for all variables, which means the uncertainty does not change significantly so no updating is required.

\subsubsection{Methodological quality uncertainty}

Based on the simplified descriptions of the methodological quality uncertainty in Table 8 by Brown et al. (2005), has the methodological quality of commonly employed test methods for determination of hydrogeological parameters been characterised as given in Table 9.

Saturated hydraulic conductivity $(K)$ : The $\mathrm{K}$ values can be determined by all test methods represented in Table 9 from point scale (laboratory measurements) to model calibration scale (typical grid size of $1 \mathrm{~km}^{2}$ ). However tracer tests are rarely used for determination of $\mathrm{K}$ values, thus the methodological quality has been found irrelevant for evaluation. The instrument quality is classified as I3 (instruments well suited for the field situation and calibrated) except the model calibration scale, where the evaluation of instrument quality is not relevant. By considering instruments under calibration in Table 9 we mean instruments related to calibration (i.e. the inversion routines such as PEST), not the instruments related to the data. Therefore the instrument uncertainty is irrelevant. The sampling strategy is showing increasing indices (i.e. increasing quality) with increasing support volume. i.e. the small scale measurements like grain sieving analysis and other laboratory measurements (e.g. leaching columns experiments or intact columns) are typically ranging between S1 to S2 indices. Slug test measurements vary even more from S1 to S3 depending on the site specific geological heterogeneity. Pump tests are giving the best coverage. Regarding the overall method indices are laboratory methods ranging significantly due to scale effects. On the other hand both specific laboratory measurements and pump test are reliable methods and they are even approved standards for measuring saturated hydraulic conductivity on laboratory and field scale. Model calibrations using inverse techniques (auto-calibration) is also a reliable and commonly used method. 
Table 8. Indices for "methodological quality" of a variable. (*) One may specify the sampling strategy in the different spatial dimensions (Ss = in space, $\mathrm{Sh}=$ horizontal, $\mathrm{Sv}=$ Vertical), and also in time $(\mathrm{St}) .(* *)$ Under "overall" method' we group the combined and described procedures to collect/transport/process/calculate the variable of interest. (From van Loon and Refsgaard, 2005).

\begin{tabular}{|c|c|c|}
\hline Instrument quality & Sampling strategy $(*)$ & Overall method $(* *)$ \\
\hline $\mathrm{I} 4$ & $\mathrm{~S} 4$ & $\mathrm{O} 4$ \\
\hline $\begin{array}{l}\text { Instrument quality is irrele- } \\
\text { vant. } \\
\text { I3 }\end{array}$ & $\begin{array}{l}\text { Full coverage, no sampling } \\
\text { involved. } \\
\text { S3 }\end{array}$ & $\begin{array}{l}\text { Approved standard in well- } \\
\text { established discipline. } \\
\text { O3 }\end{array}$ \\
\hline $\begin{array}{l}\text { Instruments well suited for } \\
\text { the field situation and cali- } \\
\text { brated. }\end{array}$ & $\begin{array}{l}\text { Large sample of direct mea- } \\
\text { surements, good sample de- } \\
\text { sign, controlled experiments } \\
\text { and cross-validation. }\end{array}$ & $\begin{array}{l}\text { Reliable method, common } \\
\text { within discipline. }\end{array}$ \\
\hline $\mathrm{I} 2$ & $\mathrm{~S} 2$ & $\mathrm{O} 2$ \\
\hline $\begin{array}{l}\text { Instruments are not well } \\
\text { matched for the field } \\
\text { situation, no calibration } \\
\text { performed. }\end{array}$ & $\begin{array}{l}\text { Indirect measurements, his- } \\
\text { torical field data, uncon- } \\
\text { trolled experiments, or small } \\
\text { sample of direct measure- } \\
\text { ments. }\end{array}$ & $\begin{array}{l}\text { Acceptable method, but lim- } \\
\text { ited consensus on reliability. }\end{array}$ \\
\hline I1 & S1 & $\mathrm{O} 1$ \\
\hline $\begin{array}{l}\text { Instruments of questionable } \\
\text { reliability and applicability. }\end{array}$ & $\begin{array}{l}\text { Educated guesses, very in- } \\
\text { direct approximations, hand- } \\
\text { book or "rule of thumb" esti- } \\
\text { mates. }\end{array}$ & $\begin{array}{l}\text { Unproven methods, ques- } \\
\text { tionable reliability. }\end{array}$ \\
\hline I0 & S0 & $\mathrm{O} 0$ \\
\hline $\begin{array}{l}\text { Instruments of unknown qual- } \\
\text { ity or applicability. }\end{array}$ & Pure guesses. & Highly subjective method. \\
\hline
\end{tabular}

Specific yield $\left(S_{y}\right)$ : Retention curve determinations on laboratory scale have instrument quality range from not well to well match of the field conditions. Keur and Vangsø (this HESS issue) describe more thoroughly the application of retention curves to determination of physical parameters on various scales. Pump tests have the highest instrument quality, best coverage of sampling strategy and is an overall reliable method. Model calibration is commonly used and seen as an acceptable method for $\mathrm{S}_{y}$ estimation but there is limited consensus on the reliability of the results.

Specific storage $\left(\mathrm{S}_{S}\right)$ has been characterised with the same indices ranking as $S_{y}$ but on laboratory scale are retentions curves exchanged with geotechnical triaxial tests to determine specific storage.

Effective porosity (n): This variable has the instrument quality well suited at both small and large scale. All test methods are ranking between educated guesses to indirect measurements. Results derived from tracer tests can among others be used for effective porosity estimation. All test methods are grouped as acceptable methods even with some specific methods appearing as approved standards for porosity measuring.

Dispersivity $(\alpha)$ : The alpha value is limited to be determined from the larger scale methods: tracer test and model calibration.
In general, the HarmoniRiB framework indices for the methodological quality increase with increasing support volume, which the different test methods represent. Individual indices show higher variability at small scale test methods compared to larger scale methods due to effects of spatial scale.

\section{Discussion and conclusions}

Uncertainty assessment is an important aspect of water resources management. First of all, water management decisions should be made with full information on the underlying uncertainties. Secondly, credibility of model predictions among stakeholders is important for achieving consensus and robust decisions. Overselling of model capabilities is "poison" for establishing such credibility. Instead, explicit information on the involved uncertainties may help creating a more balanced view on the capability of models and in this way pave the road for improving the credibility of models.

Assessments of uncertainty in hydrogeological data and conceptual models are prerequisites for assessment of uncertainty in model predictions, and as such they are crucial. Uncertainty assessments are common in the scientific community, but not yet in the professional world of water 
Table 9. Methodological quality: Instrument quality (I); Sampling strategy (S) and Overall method (O). -: test method not common/relevant for determination of specific hydraulic parameter values.

\begin{tabular}{|c|c|c|c|c|c|}
\hline Test method & $\begin{array}{l}\text { Saturated } \\
\text { hydraulic } \\
\text { conductiv- } \\
\text { ity }\end{array}$ & $\begin{array}{l}\text { Specific } \\
\text { yield }\end{array}$ & $\begin{array}{l}\text { Specific } \\
\text { storage }\end{array}$ & $\begin{array}{l}\text { Effective } \\
\text { porosity }\end{array}$ & Dispersivity \\
\hline & $(\mathrm{K})$ & $\left(\mathrm{S}_{y}\right)$ & $\left(\mathrm{S}_{s}\right)$ & (n) & $(\alpha)$ \\
\hline & I3 & - & - & I3 & - \\
\hline \multirow{2}{*}{ Grain size + formula } & $\mathrm{S} 1-\mathrm{S} 2$ & - & - & $\mathrm{S} 1-\mathrm{S} 2$ & - \\
\hline & $\mathrm{O} 2$ & - & - & $\mathrm{O} 2$ & - \\
\hline \multirow{4}{*}{ Laboratory measurements } & I3 & I2-I3 & I2-I3 & I3 & - \\
\hline & $\mathrm{S} 2$ & S2 & $\mathrm{S} 2$ & $\mathrm{~S} 2$ & - \\
\hline & $\mathrm{O} 2-\mathrm{O} 4$ & $\mathrm{O} 2-\mathrm{O} 4$ & $\mathrm{O} 2-\mathrm{O} 4$ & $\mathrm{O} 2-\mathrm{O} 4$ & - \\
\hline & I2-I3 & - & - & - & - \\
\hline \multirow[t]{3}{*}{ Slug test } & S1-S3 & - & - & - & - \\
\hline & $\mathrm{O} 2-\mathrm{O} 3$ & - & - & - & - \\
\hline & $\mathrm{I} 3$ & I3 & I3 & - & - \\
\hline \multirow{3}{*}{ Pump test } & S3-S4 & S3-S4 & S3-S4 & - & - \\
\hline & O3-O4 & $\mathrm{O} 3-\mathrm{O} 4$ & $\mathrm{O} 3-\mathrm{O} 4$ & - & - \\
\hline & - & - & - & $\mathrm{I} 3$ & I3 \\
\hline \multirow[t]{3}{*}{ Tracer test } & - & - & - & $\mathrm{S} 2$ & S2 \\
\hline & - & - & - & $\mathrm{O} 3$ & $\mathrm{O} 3$ \\
\hline & I4 & I4 & I4 & I4 & I4 \\
\hline \multirow[t]{2}{*}{ Model calibration } & S2 & S2 & S2 & S2 & S2 \\
\hline & $\mathrm{O} 3$ & $\mathrm{O} 2$ & $\mathrm{O} 2$ & $\mathrm{O} 2-\mathrm{O} 3$ & $\mathrm{O} 2-\mathrm{O} 3$ \\
\hline
\end{tabular}

management. We therefore have a major task in promoting the use of our uncertainty concepts and tools in practise.

In this paper, examples from the most current scientific literature that deal with uncertainty on model structure and uncertainty in parameter variables are given. Quantification of the uncertainty due to model structure is an area of novel interest, where only few operational methods have been developed. Some of the present techniques to describe the uncertainty related to geological model structure are presented and some strategies on interpretation of geological model structure are identified. In addition, uncertainty and scale of support in the hydrogeological data variables: saturated hydraulic conductivity, specific yield, specific storage, effective porosity and dispersivity are evaluated. The variables are related to the following test methods: grain size analysis, other laboratory measurements, slug tests, pump tests, tracer tests and model calibrations.

Uncertainty in the hydrogeological data variables is in this study characterised and assessed within the methodological framework of the HarmoniRiB classification, where the rating of the quality of methods can be given in a more structured overview. In general, the HarmoniRiB framework indices for the methodological quality increase with increasing support volume, which the different test methods represent. Individual indices shows higher variability at small scale test methods compared to larger scale methods due to effects of spatial scale. The use of the HarmoniRiB classification makes it possible to carry out systematic comparison of uncertainties arising in different data types required for evaluating the effect and cost of a measure in relation to preparing a water management plan in relation to the $\mathrm{EU}$ Water Framework Directive.

Scientifically there are two major tasks ahead of us to be solved. While the statistical tools for characterising uncertainty are well developed, it should be realised that many aspects of uncertainty cannot be quantified but have to be described qualitatively or subjectively. This applies particularly to geological uncertainty where knowledge on geological history and formation processes basically is qualitative. If we do not allow qualitative descriptions of uncertainty we exclude much of the geological knowledge. The second major challenge lies in handling of model structure uncertainty, which in case of groundwater models corresponds to uncertainty in hydrogeological conceptual models. In cases where models are used for making extrapolatory predictions, i.e. predictions beyond conditions and data for which a model was calibrated and tested, model structure uncertainty is known often to be the dominant source of uncertainty. And such extrapolations are situations where models are most needed, because relevant explicit data on the decisions variables of interest do not exist. While methods for handling uncertainty in geological data are well known we 
have a major challenge in developing and testing concepts for handling model structure uncertainty, and to make best possible use of qualitative geological knowledge in this context.

Acknowledgements. The present work was carried out within the Project "Harmonised Techniques and Representative River Basin Data for Assessment and Use of Uncertainty Information in Integrated Water Management (HarmoniRiB)", which is partly funded by the EC Energy, Environment and Sustainable Development programme (Contract EVK1-CT2002-00109)

Edited by: J. Freer

\section{References}

Anderson, M. P.: Hydrogeologic facies models to delineate largescale spatial trends in glacial and glaciofluvial sediments, Geological Society America Bulletin, 101, 501-511, 1989.

Anderson, M. P. and Woessner, W. W.: Applied groundwater modelling, simulation of flow and advective transport. Academic Press, San Diego, California, 1992

Bersezio, R., Bini, A., and Giudici, M.: Effects of sedimentary heterogeneity on groundwater flow in a Quaternary pro-glacial delta environment: joining facies analysis and numerical modelling, Sedimentary Geology, 129, 327-344, 1999.

Bradbury, K .R. and Muldoon, M. A.: Hydraulic conductivity determination in lithified glacial and fluvial materials, In: Ground Water and Vadose Zone Monitoring, ASTM STP 1053, edited by: Nielsen, D. M. and Johnsen, A. I., American Society for testing Materials, Philadelphia, 138-151, 1990.

Brown, J. D., Heuvelink, G. B. M., and Refsgaard, J. C.: An integrated framework for assessing and recording uncertainties about environmental data, Water Sci. Technol., 52(6), 153-160, 2005.

Brown JD and Heuvelink GBM: Data Uncertainty Engine (DUE) User's Manual. University of Amsterdam. http://www. harmonirib.com, 2006.

Carrera, J. and Neuman, S. P.: Estimation of aquifers parameters under transient and steady state conditions: 1. Maximum likelihood method incorporating prior information, Water Resour. Res., 22, 199-210, 1986.

Carle, S. F. and Fogg, G. E.: Transition probability based on indicator geostatistics, Mathematical Geology, 28, 453-477, 1996.

Carle, S. F. and Fogg, G. E.: Modelling spatial variability with one and multidimensional continuous-lag Markov chains, Mathematical Geology, 29, 891-917, 1997.

Clauser, C.: Permeability of crystalline rocks, Eos 73, 233-238, 1992.

Cooley, R. L.: A theory for modelling ground-water flow in heterogeneous media. U.S.G.S. Professional Paper, vol. P 1679. U.S. Geological Survey, Denver, CO, 220 pp., 2004.

Dagan, G.: Statistical theory of groundwater flow and transport: Pore to laboratory, laboratory to formation and formation to regional scale, Water Resour. Res., 22(9), 120S-134S, 1986.

Dagan, G., Fiori, A., and Jankovi, I.: Flow and transport in highly heterogeneous formations : 1 . Conceptual framework and validity of first-order approximations, Water Resour. Res., 39, 1268, doi:10.1029/2002WR001717, 2003. de Marsily, G., Delay, F., Teles, V., and Schafmeister, M. T.: Some current methods to represent the heterogeneity of natural media in hydrogeology, Hydrogeol. J., 6(1), 115-130, 1998.

Eaton, T.: On the importance of geological heterogeneity for flow simulation, Sedimentary Geology, 184, 187-201, 2006.

European Commission: EU Water Framework Directive (Directive 2000/60/EC). European Parliament and Commission, Official Journal (OJ L 327) on 22 December 2000.

Fogg, G. E.: Groundwater flow and sand body interconnectedness in a thick multiple aquifer system, Water Resour. Res., 22, 679694, 1986.

Fogg, G. E., Noyes, C. D., and Carle, S. F.: Geologically based model of heterogeneous hydraulic conductivity in an alluvial setting, Hydrogeol. J., 6(1), 131-143, 1998.

Fraser, G. S. and Davis, J. M. (Eds.): Hydrogeologic models of sedimentary aquifers, SEPM Concepts in Hydrology and Environmental geology, vol. 1. Society for Sedimentary Geology, Tulsa, OK. 180 pp., 1998.

Freeze, R. A. and Cherry, J. A.: Groundwater. Prentice Hall, Englewood Cliffs, NJ 07632, USA, 1979.

Funtowicz, S. O. and Ravetz, J. R.: Uncertainty and Quality in Science for Policy. Kluwer, Dordrecht; 229 p., 1990.

Gelhar, L. W.: Stochastic subsurface hydrology from theory to application, Water Resour. Res., 22(9), 135S-145S, 1986.

Gelhar, L. W.: Stochastic subsurface hydrology, Englewood Cliffs, NJ, Prentice Hall, 1993.

Harrar, W. G., Sonnenborg, T. O., and Henriksen, H. J.: Capture zone, travel time and solute transport predictions using inverse modelling and different geological models, Hydrogeol. J., 11, 536-548, 2003.

Henriksen, H. J., Troldborg, L., Nyegaard, P., Sonnenborg, T. O., Refsgaard, J. C., and Madsen, B.: Methodology for construction, calibration and validation of a national hydrological model for Denmark, J. Hydrol., 280, 52-71, 2003.

Højberg, A. L. and Refsgaard, J. C.: Model Uncertainty - Parameter uncertainty versus conceptual models, Water Sci. Technol., 52(6), 177-186, 2005.

Isaaks, E. D. and Srivastava, R. M.: An Introduction to Applied Geostatistics. Oxford University Press, New York, USA, 1989.

Klingbeil, R., Kleineidam, S., Asprion, U., Aigner, T., and Teutsch, G.: Relating lithofacies to hydrofacies: Out-crop hydrogeological characterization of Quaternary gravel deposits, Sedimentary Geology, 129, 299-310, 1999.

Koltermann, C. E. and Gorelick, S. M.: Heterogeneity in sedimentary deposits: A review of structure-imitating, process-imitating and descriptive approaches, Water Resour. Res., 32, 2617-2658, 1996.

Kupfersberger, H. and Deutsch, C. V.: Ranking stochastic realizations for improved aquifer response uncertainty assessment, J. Hydrol., 223(1-2), 54-65, 1999.

National Research Council: Conceptual models of flow and transport in vadose zone. National Academy Press, Washington, DC., 2001.

Neuman, S. P. and Weirenga, P. J.: A comprehensive strategy of hydrogeologic modelling and uncertainty analysis for nuclear facilities and sites, NUREG/CR-6805, 2003.

Nilsson, B., Sidle, R. C., Klint, K. E., Bøggild, C. E., and Broholm, K.: Mass transport and scale-dependent hydraulic tests in a heterogeneous glacial till-sandy aquifer system, J. Hydrol., 243, 
162-179, 2001.

Petersen, D. L., Jensen, K. H., and Nilsson, B.: Effect of embedded sand lenses on transport in till. Eos, Transactions, American Geophysical Union, 85(47), Fall Meeting, 2004

Poeter, E. M. and Anderson, D.: Multimodel ranking and inference in ground water modelling, Groundwater, 43(4), 597-605, 2005.

Poeter, E. M. and Hill, M. C.: Inverse methods: A necessary next step in ground water modelling, Groundwater, 35(2), 250-260, 1997.

Refsgaard, J. C., Nilsson, B., Brown, J., Klauer, B., Moore, R., Bech, T., Vurro, M., Blind, M., Castilla, G., Tsanis, I., and Biza, P: Harmonised Techniques and Representative River Basin Data for Assessment and Use of Uncertainty Information in Integrated Water Management (HarmoniRiB), Environmental Science and Policy, 8, 267-277, 2005.

Refsgaard, J. C., van der Sluijs, J. P., Brown, J., and van der Keur, P.: A framework for dealing with uncertainty due to model structure error, Adv. Water Resour., 29(11), 1586-1597, 2007a.

Refsgaard, J. C., van der Keur, P, Nilsson, B., Müller-Wohlfeil, D.I., and Brown, J.: Uncertainties in river basin data at various support scales - examples from Odense Pilot River Basin, Hydrol. Earth Syst. Sci. Discuss., 3, 1943-1985, 2006 b.

Ritzi Jr., R. W., Dominic, D. F., Slesers, A. J., Greer, C. B., Reboulet, E. C., Telford, J. A., Masters, R. W., Klohe, C. A., Bogle, J. L., and Means, B. P.: Comparing statistical models of physical heterogeneity in buried-valley aquifers, Water Res. Res., 36(11), 3179-3192, 2000.

Ritzi, R. W., Jayne, D. F., Zahradink, A. J., Field, A. A., and Fogg, G. E.: Geostatistical modeling of heterogeneity in glaciofluvial, buried-valley aquifers, Ground Water, 32(4), 666-674, 1994.

Rode, M. and Suhr, U.: Uncertainties in selected surface water quality data, Hydrol. Earth Syst. Sci. Discuss., 3, 2991-3021, 2006, http://www.hydrol-earth-syst-sci-discuss.net/3/2991/2006/.

Samper, J., Carrera, J., Galarza, G., and Medina, A.: Application of an automatic calicration technique to modelling an alluvial aquifer, IAHS AISH Publication, 195, 87-95, 1990.

Sánchez-Vila, X., Girardi, J., and Carrera, J.: Scale effects in transmissivity, J. Hydrol., 183, 1-22, 1996.

Selroos, J. O., Walker, D. D., Strom, A., Gylling, B., and Follin, S.: Comparison of alternative modelling approaches for groundwater flow in fractured rock, J. Hydrol., 257, 174-188, 2001.

Sminchak, J. R., Dominic, D. F., and Ritzi, R. W.: Indicator geostatistical analysis of sand interconnections within a till, Ground Water, 34(6), 1125-1131, 1996.
Smith, L. and Weathcroft, S. W.: Groundwater flow In: Maidment DR (Ed. in chief), Handbook of Hydrology, Mc Graw-Hill Inc., 1992.

Sonnenborg, T. O.: Kalibrering af strømningsmodel, in: Ståbi i grundvandsmodellering, edited by: Henriksen, H. J., Refsgarrd, J. C., Sonnenborg, T. O., et al., GEUS report, No. 56, 2001.

Troldborg, L.: Effects of geological complexity on groundwater age prediction, Eos, Transactions, American Geophysical Union, 81(48), F435, 2000.

Troldborg, L.: The influence of conceptual geological models on the simulation of flow and transport in Quaternary aquifer systems. $\mathrm{PhD}$. Thesis. Geological Survey of Denmark and Greenland, Report 2004/107, 2004.

van der Keur, P. and Iversen, B. V.: Uncertainty in soil physical data at river basin scale - a review, Hydrol. Earth Syst. Sci., 10, 889902, 2006,

http://www.hydrol-earth-syst-sci.net/10/889/2006/.

van Loon, E. and Refsgaard, J. C. (Eds.): Guidelines for assessing data uncertainty in hydrological studies. HarmoniRiB Report. Geological Survey of Denmark and Greenland, http://www. harmonirib.com, 2005.

van Loon, E., Brown, J. D., and Heuvelink, G. M. B.: Metodological Considerations. Chapter 2 in: 2005. Guidelines for assessing data uncertainty in hydrological studies, edited by: Van Loon, E. and Refsgaard, J. C., HarmoniRiB Report. Geological Survey of Denmark and Greenland, http://www.harmonirib.com, 2005.

Weissmann, G. S., Carle, S. F. and Fogg, G. E.: Three dimensional hydrofacies modeling based on soil surveys and transition probability geostatistics, Water Resour. Res., 35(6), 1761-1770, 1999.

Weissmann, G. S. and Fogg, G. E.: Multi-scale alluvial fan heterogeneity modelled with transition probability geostatistics in a sequence stratigraphic framework, J. Hydrol., 226(1-2), 48-65, 1999.

Willis, B. J. and White, C. D.: Quantitative outcrop data for flow simulation, J. Sedimentary Res., 70(4), 788-802, 2000.

Zimmerman, D. A., de Marsily, G., Gotway, C. A., Marietta, M. G., Axness, C. L., Beauheim, R. L., Bras, R. L., Carrera, J., Dagan, G., Davies, P. B., Gallegos, D. P., Galli, A., Gomez-Hernandez, J., Grindrod, P., Gutjahr, A. L., Kitanidis, P. K., Lavenue, A. M., McLaughlin, D., Neuman, S. P., RamaRao, B. S., Ravenne, C., and Rubin, Y.: A comparison of seven geostatistically based inverse approaches to estimate transmissivities for modeling advective transport by groundwater flow, Water Resour. Res., 34(6), 1373-1413, 1998. 